Agricultural Research Council Savings plans

The British Agricultural Research Council (ARC) is still in a fix about its budget for the next three years. Plans to find all the necessary economies to meet the expected shortfall in its government grant at the Animal Breeding Research Organization (ABRO) and the Long Ashton Research Station have been abandoned. A decision on the future of the two institutes, which was to have been taken at the end of last month, has been put off to the end of April, and the council has set up a "core group", to look for comparable savings elsewhere.

ARC had originally planned to save the expected $\mathbf{f} 3$ million deficit in its annual budget by cutting research on food, beverages and fruit at Long Ashton and by cutting back ABRO to fundamental animal genetics. It has, however, found its hands tied by the Rothschild customer-contractor principle, whereby the Ministry of Agriculture (the customer) commissions a substantial proportion of research in ARC institutes (the contractors). The ministry, aided by the livestock industry, seems to have objected strongly to the plan to cut ABRO to one-fifth of its present strength. Such is the colour of the ministry's money, however, that at one stage it had almost persuaded ARC to cut fundamental rather than applied research. In the event, ARC last week produced a revised plan that may get it off that hook.

The revised plan being circulated for consultation before a final decision on 20 April entails a 50 per cent cut in ABRO's annual budget, from $£ 2.25$ million to $£ 1.2$ million, by $1984-85$, but keeps the balance between fundamental and applied research roughly the same as now. Work on the long-term breeding of sheep and pigs and on the efficiency of dairy cows would continue, as would several areas of animal genetics. ARC says that it may also find a further $£ 0.4$ million for research in molecular biology later on. The council clearly hopes its new plan will have an easy passage.

The proposals for the Long Ashton Research Station, which have caused less of a stir, are likely to stand. Hence some research will probably be moved to the East Malling Research Station and the fruit industry is being asked to increase its support for the remaining programmes.

The debate over the future of the two institutes nevertheless has wider implications. ARC's own staff has complained that the process of regularly reviewing research programmes is not sufficiently open. It is also clear that the council needs some way of deciding priorities within as well as between institutes. But the most telling lesson of the past few days is the council's discovery that under the customer-contractor principle, the customer is ultimately (if not always) right.

Judy Redfearn

\title{
Not enough toxicologists in Europe?
}

The European Science Foundation (ESF) and the European Medical Research Council (EMRC) have announced a new programme for research and training in toxicology. A number of awards will be made in 1983 along the lines of ESF's existing brain research programme.

EMRC is basically a talking shop for ESF, representing members of the governing bodies of 14 Western European medical research councils who meet twice a year, and directors of the regional office of the World Health Organization and of the National Institute of Health in Bethesda, Maryland have a standing invitation to attend meetings. Toxicology has been a major interest of EMRC since it was established in 1971, and now nine members of EMRC have put up the money for the toxicology programme; the 1982 budget is FF700,000 ( $£ 63,600)$.

Although the demand for toxicologists in industry and government is growing rapidly, toxicology remains an ill-defined subject which may mean different things in France and, say, Denmark.

\section{Soviet science and technology \\ Practical slant}

The Soviet Academy of Sciences seems to be planning a more direct interest in production research, according to $\mathrm{Dr}$ Anatolii Aleksandrov, the president, in his address to the academy's annual meeting. The academy's increased participation in technological projects in the past eighteen months seems to be connected with the appointment of Dr Gurii Marchuk, formerly chairman of the Siberian branch of the academy, as head of the State Committee for Science and Technology.

When Dr Marchuk moved to the state committee, which is responsible for applied research and its implementation, he urged greater use of the academy's talents in implementing research results in production - thus bridging what has become a major planning gap.

The academy's new practical slant is clearly approved by Dr Aleksandrov, who has often stressed that the Soviet Union is potentially independent of foreign research and development. By contrast, the chief academic secretary of the academy, Dr Georgii Skryabin, told the annual meeting of his regret that the deterioration of the international situation has led to reduced contact with the West. He particularly deplored the cutback in exchanges with the United States - although the US National Academy of Sciences had asked for talks to continue on international security and arms control. Contacts with the United Kingdom, on the other hand, had, he said, "become more active".

Vera Rich
EMRC has recommended that priority should be given to mechanisms of toxicity and the epidemiology of exposure to chemicals. It also emphasizes the need for more research in toxicology and the inclusion of toxicology in the university curriculum. In the United Kingdom, for example, toxicologists are drawn mainly from pathology and biochemistry, and the subcommittee report on which the ESF programme is based is impressed with the complaint from industry that university graduates lack practical training in toxicology.

As well as travel and subsistence grants for training courses, ESF plans to award one-year training fellowships to graduates from toxicology-related disciplines. There will also be renewable fellowships for people already working as toxicologists for projects involving collaboration with teams abroad.

ESF is optimistic about the programme. It is to be hoped that the length of time it has taken to set up the new programme is not indicative of the pace at which all collaborative European research will develop.

Jane Wynn

\section{University research funding} \section{Line of defence}

\section{Washington}

US universities and colleges continue to benefit from Washington's current enthusiasm for increasing its expenditure on military technologies and related national security needs. A subcommittee of the House of Representatives has now approved a provisional bill, said to have wide support within the Administration, which would allocate up to $\$ 100$ million a. year to improve facilities in higher education institutions in technical subjects important for security interests.

The explicit purpose of the legislation is to increase the ability of the United States to meet both its immediate defence needs and the technological demands that would be created by a prolonged war.

The legislation is supported by the Department of Defense, the Department

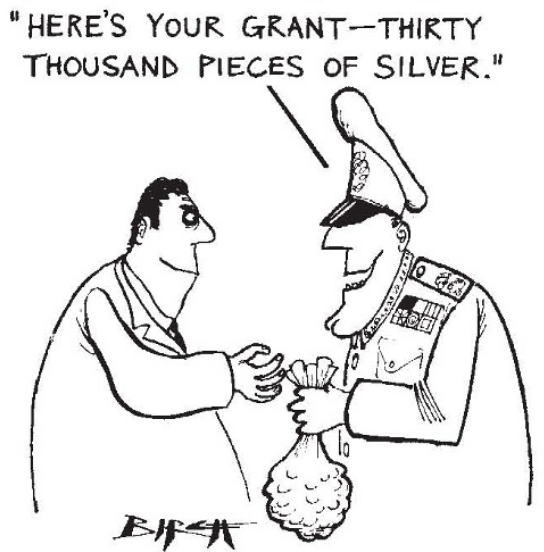

